(RESEARCH ARTICLE)

\title{
Effect of natural zeolites and zeolites added with microorganisms for the growth of cabbage (Brassica oleracea var. capitata L.)
}

\author{
Prisa Domenico * \\ CREA Research Centre for Vegetable and Ornamental Crops, Council for Agricultural Research and Economics, Via dei \\ Fiori 8, 51012 Pescia, PT, Italy.
}

Publication history: Received on 22 October 2018; revised on 07 November 2019; accepted on 10 November 2019

Article DOI: https://doi.org/10.30574/wjarr.2019.4.1.0078

\begin{abstract}
In this study the effect of natural zeolites and zeolites added with micro-organisms for the growth of cabbage (Brassica oleracea var. capitata $L$.) was evaluated, in order to highlight whether the microbiological component is the basis of the functionality of zeolites. The 3 experimental groups in cultivation were: 1) group without zeolites (CTRL) (peat 100\%), irrigated with water and substrate previously fertilized; group with natural chabazite (CN) and fertilised substrate; group with chabazite enriched with micro-organisms (CM) and fertilised substrate. (Patented formula rif.28106IT/MB/BF). The test showed a significant increase in the agronomic parameters analyzed in plants treated with natural zeolites and zeolites with the addition of micro-organisms compared to the control. Also with regard to the physiological analysis of plants there was a significant increase in the parameters analysed, in the thesis treated with zeolites with the addition of micro-organisms and natural zeolites compared to the control. Finally, it should be noted that in the thesis treated with zeolites enriched with micro-organisms and in that with natural zeolites, the experiment also showed an increase in the percentage of germination of seeds and a significant reduction in the average time of germination compared to the untreated control (CTRL). The use of zeolites, as demonstrated by this test, can guarantee the grower a qualitative improvement of the plants in cultivation, ensuring better management of the use of fertilizers and water for irrigation. The zeolites are able to interact actively with the organic components present in the soil or brought with the fertilization, and have the ability to make more available the mineral and nutritional components present within their crystal lattice, based on the needs of the plant.
\end{abstract}

Keywords: Vegetables; Greenhouse cultivation; Plant fortifier; Rhizosphere; Plant quality

\section{Introduction}

The cultivation of cabbage in Italy has declined considerably in recent years. Its cultivation is practiced in all Italian regions, with a greater diffusion in the Centre-South. In Europe, this crop is particularly important in Germany, where cabbage is grown both for the fresh market and for industrial processing. Like most cabbage forms grown today, cabbage also originates in Europe. It is thought to derive from Brassica oleracea var. acephala DC. due to deformation of the cauline bud. It belongs to the Cruciferae family and is a biennial plant [1]. Cabbage prefers cold and humid temperate climates, but some cultivars however grow and produce well even in warm temperate climate conditions which however must never be dry. It thrives well in all types of soil, as long as it is deep, well aerated and fresh. The reaction of the soil is very important: the optimal $\mathrm{pH}$ is around neutrality $(6,5-7,2)$, while at acid $\mathrm{pH}$ there is a reduction in production and greater susceptibility to biotic stress [1].

The zeolites are utilized in agriculture, because they have several interesting characteristics, in particular: i) cation exchange capacity (CSC): within its structure, zeolite has mobile cations that can be removed and replaced with others or exchanged. In addition, there is a selectivity scale which indicates the tendency of the exchanger to give cations to

\footnotetext{
${ }^{*}$ Corresponding author

E-mail address: domenico.prisa@crea.gov.it
} 
the aqueous phase, replacing them with those to which it is more akin. The preferred cations are those of small charge and large radius such as potassium $\left(\mathrm{K}^{+}\right)$, ammonium $\left(\mathrm{NH}_{4}^{+}\right)$, cesium $\left(\mathrm{Cs}_{2}{ }^{+}\right)$, etc.. ii) high absorption capacity and hydrophilicity (reversible dehydration): the water in the channels and cavities of the zeolite can be removed by heating, leaving the channels free and ready to absorb, by simple cooling, the atmospheric humidity. This process can be repeated indefinitely. Commercial use of natural zeolites is still in its infancy, but more than 300,000 tons of zeolite-rich tuff is extracted annually in the United States, Japan, Bulgaria, Hungary, Italy, Yugoslavia, Korea, Mexico, Germany, and the Soviet Union [2]. Natural zeolites have found applications as fillers in the paper industry, as light aggregates in construction, cement and concrete, as ion exchangers in water purification and municipal effluent purification, as traps for radioactive species in wastewater from nuclear plants, in oxygen production, as catalysts for oil fields, as acidresistant absorbents and in the drying and purification of natural gas $[3,4]$. The pronounced selectivity of zeolite for large cations, such as ammonium and potassium, has also been exploited in the preparation of chemical fertilizers that improve the capacity of retention of nutrients in soils promoting a slower release of these elements for absorption by plants, in rice fields, where losses by runoff of $50 \%$ of nitrogen supplied are frequent. Zeolites have been used in this experiment because they have several interesting characteristics for use in agriculture, in particular in horticulture, the use of zeolites in table tomatoes [5], celery [6], courgettes and melons [7], vegetables and fruit [8,9] has led to an increase in the total production of finished product per hectare of land. In floriculture, the use of zeolites has led to an increase in height in the total number of inflorescences, buds, flowers, the size of the bulbs and a higher precociousness of flowering in geranium $[10,8,9]$ and the qualitative improvement and resistance to biotic and abiotic stress of other ornamental species $[11,12,13]$.

In this study the effect of natural zeolites and zeolites added with micro-organisms for the growth of cabbage (Brassica oleracea var. capitata L.) was evaluated, in order to highlight whether the microbiological component is the basis of the functionality of zeolites.

\section{Material and methods}

\subsection{Greenhouse experiment and growing conditions}

The experiments, started in February 2019, were conducted in the greenhouses of CREA-OF in Pescia (Pt), Tuscany, Italy $\left(43^{\circ} 54^{\prime} \mathrm{N} 10^{\circ} 41^{\prime} \mathrm{E}\right)$ on cabbage plants. The plants were placed in pots $\emptyset 14 \mathrm{~cm} ; 60$ tense plants, divided into 3 replicas of 20 plants each. All plants were fertilized with a controlled release fertilizer $\left(5 \mathrm{~kg} \mathrm{~m}^{-3}\right.$ 0smocote Proß, 6 months with $190 \mathrm{~g} / \mathrm{kg} \mathrm{N}, 39 \mathrm{~g} / \mathrm{kg} \mathrm{P}, 83 \mathrm{~g} / \mathrm{kg} \mathrm{K}$ ) mixed with the culture medium before transplanting. The 3 experimental groups in cultivation were:

Group without zeolites (CTRL) (peat 100\%), irrigated with water and substrate previously fertilized;

Group with natural chabazite (CN) (peat 80\% + chabazite 20\%) and fertilised substrate;

Group with chabazite enriched with micro-organisms (CM) (peat 80\% + chabazite 20\%) and fertilised substrate. (Patented formula rif.28106IT/MB/BF)

All chabazite products were supplied by Balco Greenline of Sassuolo (M0). The chabazitic- zeolites had the following characteristics: 1) qualitative-quantitative mineralogical analysis (\% by weight with standard deviations in brackets) carried out by X-ray powder diffractogram according to the RIETVELDRIR methodology [14]: chabazite 66.2 (1.0); phillipsite 2.4 (0.5); mica 5.6 (0.6); K-feldspar 10.3 (0.8); pyroxen 2.2 (0.5); volcanic glass 13.3 (1.5); 2) Total zeolithic content (\%): 68.6 (1.3), of which 66.2 due to chabazite and 2.4 from phillipsite. Cation exchange capacity (in meq/g with standard deviation in brackets) determined using the methodology described in Gualtieri et al. (1999) [15]: 2.15 (0.15) of which 1.42 due to $\mathrm{Ca}, 0.04$ to $\mathrm{Mg}, 0.05$ to $\mathrm{Na}$ and 0.64 to $\mathrm{K}$. The chabazite with added microorganisms had a microbial count of $4.2 \times 10^{6} \mathrm{ufc} / \mathrm{g}$ of zeolites. The $\mathrm{pH}$ of the zeolite was 6.9. For the experimentation of plant growth was used $\varnothing 3-$ $6 \mathrm{~mm}$.

The plants were watered 3 times a week and grown for 6 months. The plants were irrigated with drip irrigation. The irrigation was activated by a timer whose program was adjusted weekly according to climatic conditions and the fraction of leaching. On July 15, 2019, the number of leaves, the vegetative and root weight, and the stem diameter were recorded.

Ten days before the destructive analysis, the chlorophyll content was evaluated (FieldScout CM 1000 Chlorophyll Meter; SPAD index was measured on three leaves of each plant (180 measurements per treatment), net photosynthesis (Pn) (LI-6400XT Portable Photosynthesis System). 
At the same time, a seed germination test was carried out using the same substrates as the cultivation test. In this study the percentage of seeds germination and the average germination time were evaluated (100 seeds were used for three replicas per type of substrate). The particle size of the zeolites for the germination test was $0-3 \mathrm{~mm}$.

\subsection{Statistics}

The experiment was conducted in a complete randomized block drawing. The collected data were analyzed in an ANOVA way, using the univariate GLM procedure, to evaluate significant differences $(P \leq 0.05,0.01$ and 0.001$)$ between treatments. The mean values were then separated by the multiple range LSD test $(\mathrm{P}=0.05)$. Statistics and graphs were supported by the Costat (version 6.451) and Excel (Office 2010) programs.
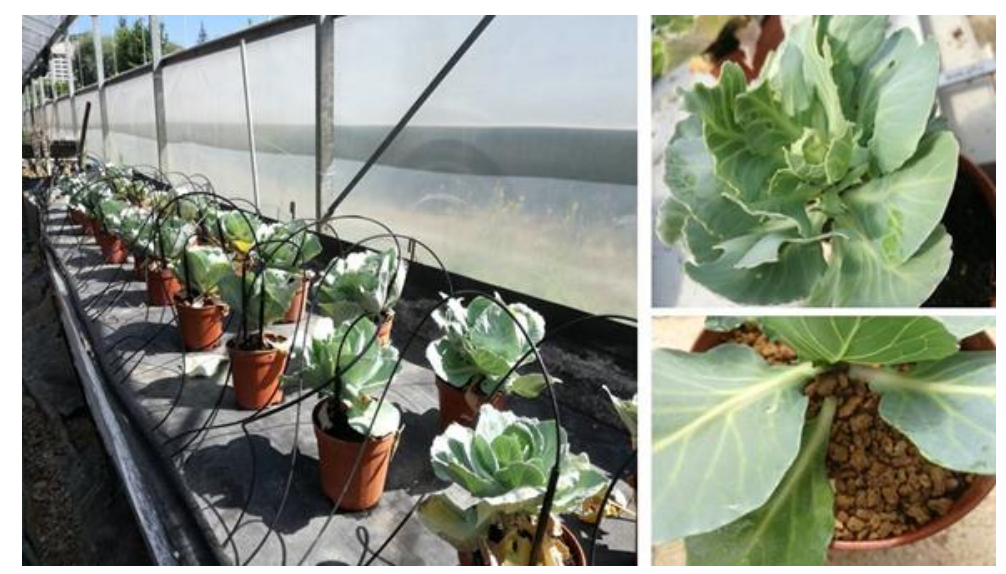

Figure 1 Detail of the greenhouse cultivation of cabbage and chabazitic-zeolites in pots

\section{Results}

\subsection{Plant growth}

The test showed a significant increase in the agronomic parameters analyzed in plants treated with natural zeolites and zeolites with the addition of micro-organisms compared to the control (Table 1). In fact, all plants treated with (CM) and $(\mathrm{CN})$ showed a significant increase in the number of leaves, vegetative and radical weight and stem diameter compared to the untreated control. In particular, there was also a significant increase in the agronomic parameters of micro-organism based zeolites (CM) compared to natural zeolites (CN).

In cabbage the number of leaves was 41.58 for (CM), 34.67 for (CN), compared to 24.25 for the control. There was a significant increase in vegetative biomass in (CM) 91,48 $\mathrm{g}$ and 71,69 $\mathrm{g}$ (CN) compared to 62,47 $\mathrm{g}$ (CTRL) (Figure 2). The same trend can be observed for root biomass where in (CM) there is $49.99 \mathrm{~g}$, in (CN) $44.21 \mathrm{~g}$ and in the untreated control $33.26 \mathrm{~g}$ (Figure 3). There was also a significant increase in stem diameter with $14.90 \mathrm{~mm}$ in (CM), $12.37 \mathrm{~mm}$ in (CN) and $10.28 \mathrm{~cm}$ in (CTRL).

Table 1 Evaluation of the effect of zeolites on cabbage growth

\begin{tabular}{ccccc}
\hline Groups & $\begin{array}{c}\text { Leaves } \\
\text { number } \\
\left(\mathbf{n}^{\circ} \mathbf{)}\right.\end{array}$ & $\begin{array}{c}\text { Vegetative } \\
\text { weight } \\
\mathbf{( g )}\end{array}$ & $\begin{array}{c}\text { Root } \\
\text { weight } \\
\mathbf{( g )}\end{array}$ & $\begin{array}{c}\text { Stem } \\
\text { diameter } \\
\mathbf{( m m}\end{array}$ \\
\hline CTRL & $24,25^{\mathrm{c}}$ & $62,47^{\mathrm{c}}$ & $33,26^{\mathrm{c}}$ & $10,28^{\mathrm{c}}$ \\
$\mathrm{CN}$ & $34,67^{\mathrm{b}}$ & $71,69^{\mathrm{b}}$ & $44,21^{\mathrm{b}}$ & $12,37^{\mathrm{b}}$ \\
$\mathrm{CM}$ & $41,58^{\mathrm{a}}$ & $91,48^{\mathrm{a}}$ & $49,99^{\mathrm{a}}$ & $14,90^{\mathrm{a}}$ \\
\hline ANOVA & $* * *$ & $* * *$ & $* * *$ & $* * *$ \\
\hline
\end{tabular}

One-way ANOVA; n.s. - non significant; ${ }^{*}, * * * * *$ significant at $\mathrm{P} \leq 0.05,0.01$ and 0.001 , respectively; different letters for the same element indicate significant differences according to Tukey's (HSD) multiple-range test $(\mathrm{P}=0.05)$.

Legend: group without chabazite (CTRL); group with natural chabazite (CN); group with chabazite enriched with micro-organisms (CM). 
Also with regard to the physiological analysis (Table 2) of plants there was a significant increase in the parameters analyzed in the thesis treated with zeolites with the addition of micro-organisms and natural zeolites compared to the control. In particular, there was a significant increase in the chlorophyll content, 15.48 (CM) compared to 14.25 (CN) and 13.38 of the untreated control.

As for the net leaf photosynthesis rate (Pn), there was a significant increase in plants treated with zeolites (CM) 13.97 $\mu \mathrm{mol} \mathrm{m} \mathrm{m}^{-2} \mathrm{~s}^{-1}$ and $12.32 \mu \mathrm{mol} \mathrm{m}^{-2} \mathrm{~s}^{-1}$ (CN) compared to $11.78 \mu \mathrm{mol} \mathrm{m} \mathrm{m}^{-2} \mathrm{~s}^{-1}$ in (CTRL). However, there are no significant differences between the two kinds of zeolites.

Table 2 Evaluation of the effect of zeolites on the physiological characteristics of cabbage

\begin{tabular}{|c|c|c|}
\hline Groups & $\begin{array}{l}\text { Chlorophyll } \\
\text { content } \\
\text { (spad index) }\end{array}$ & 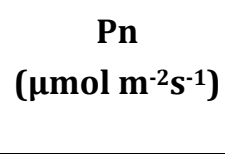 \\
\hline CTRL & $13,38^{c}$ & $11,78^{b}$ \\
\hline $\mathrm{CN}$ & $14,25^{b}$ & $12,32^{b}$ \\
\hline $\mathrm{CM}$ & $15,48^{a}$ & 13,97 a \\
\hline ANOVA & $* * *$ & $* * *$ \\
\hline
\end{tabular}

One-way ANOVA; n.s. - non significant; ${ }^{* * * * * * *}$ - significant at $\mathrm{P} \leq 0.05,0.01$ and 0.001 , respectively; different letters for the same element indicate significant differences according to Tukey's (HSD) multiple-range test $(\mathrm{P}=0.05)$

Legend: Leaf net photosynthesis rate (Pn), chlorophyll (SPAD index) content. group without chabazite (CTRL); group with natural chabazite (CN); group with chabazite enriched with micro-organisms (CM).

In the thesis treated with zeolites enriched with micro-organisms and natural zeolites, the experiment also showed an increase in the percentage of seed germination and a significant reduction in the average germination time (Table 3 ) compared to the untreated control (CTRL). $93 \%$ of seeds germinated in (CM), $89 \%$ in (CN) compared to $82 \%$ of the control (CTRL). While 8.83 days for seed germination in (CM), 10.25 days in (CN) and 13.33 days in (CTRL) control. This improvement in seed germination can be due both to a more homogeneous moisture content of the zeolite-based substrate $(\mathrm{CN})$, and to the direct action of the micro-organisms contained in (CM), which in addition to stimulating seed germination can control possible pathogens harmful to seedlings. Aspects not found in the control substrate.

Table 3 Evaluation of the effect of zeolites in the germination of cabbage.

\begin{tabular}{ccc}
\hline Groups & $\begin{array}{c}\text { Seed germination } \\
\mathbf{( \% )}\end{array}$ & $\begin{array}{c}\text { Average } \\
\text { germination } \\
\text { time (days) }\end{array}$ \\
\hline CTRL & 82 & $13,33^{\mathrm{a}}$ \\
CN & 89 & $10,25^{\mathrm{b}}$ \\
$\mathrm{CM}$ & 93 & $8,83^{\mathrm{c}}$ \\
\hline ANOVA & - & $* * *$
\end{tabular}

One-way ANOVA; n.s. - non significant; ${ }^{* * *}, * * *-$ significant at $\mathrm{P} \leq 0.05,0.01$ and 0.001 , respectively; different letters for the same element indicate significant differences according to Tukey's (HSD) multiple-range test $(\mathrm{P}=0.05)$.

Legend: group without chabazite (CTRL); group with natural chabazite (CN); group with chabazite enriched with micro-organisms (CM). 


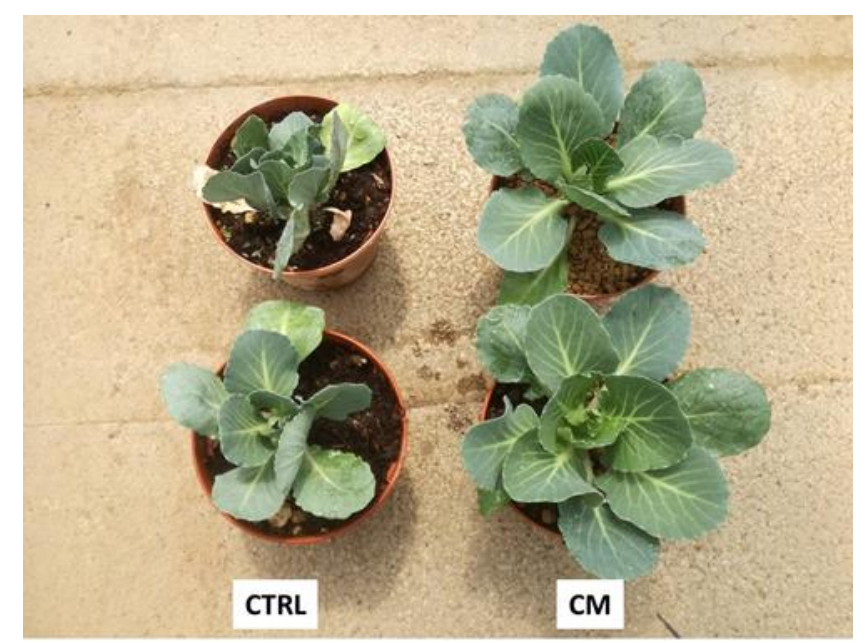

Figure 2 Effect of chabazitic-zeolites with added micro-organisms on the vegetative growth of cabbage. Legend: (CTRL) group without chabazite; (CM) chabazite enriched with micro-organisms.

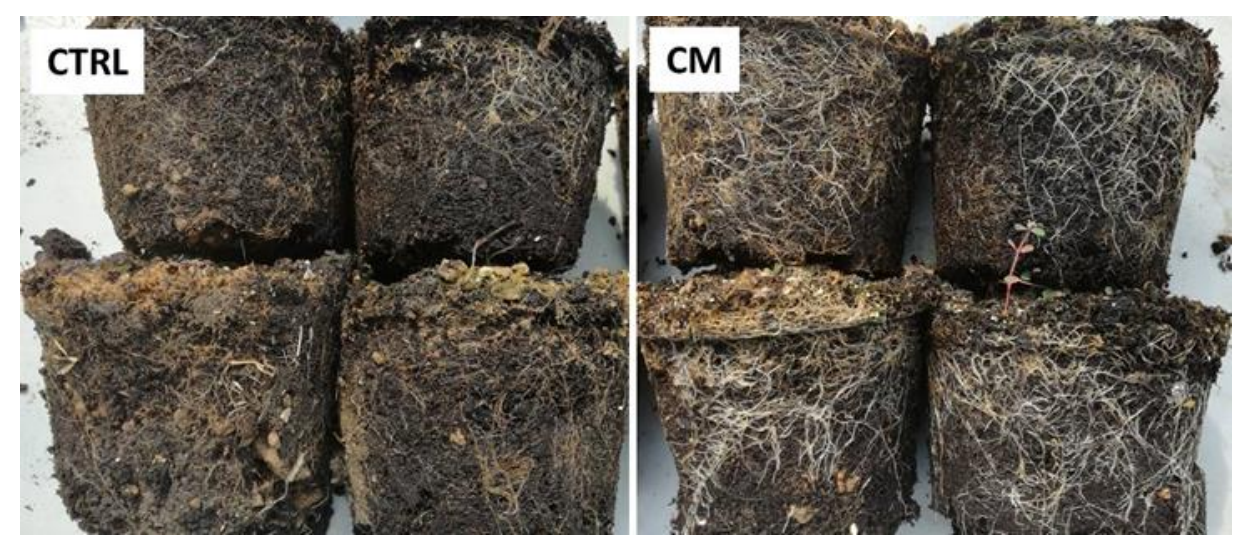

Figure 3 Effect of chabazitic-zeolites with added micro-organisms on the roots growth of cabbage. Legend: (CTRL) group without chabazite; (CM) chabazite enriched with micro-organisms.

\section{Discussion}

The use of zeolites, as demonstrated by this test, can guarantee the grower a qualitative improvement of the plants in cultivation, ensuring better management of the use of fertilizers and water for irrigation. Zeolites and, more in particular, chabasite, in fact, once introduced in the substrates of cultivation or in open field, can increase the quality of the plants, determining in particular a better germination of the seeds and rooting of the plants, an increase of the vegetable biomass and of the blooms [9]. This can be attributed both to a better water supply, to the cationic exchange capacity of the zeolites, and to the microbial nature which characterizes them [16]. In this experiment, it is noted above all that the substrates enriched with zeolites for the cultivation of cabbage have determined a significant increase in all the agronomic parameters analysed (number of leaves, vegetative and radical biomass, stem diameter). In particular, plants grown in chabazite with the addition of micro-organisms have a significantly higher root weight than other theses, which is particularly important in the post-transplant phases in the open field, both vegetable and ornamental plants, when it increases mortality due to water and nutrient stress due to poor root function. The evidence shows that zeolites can also lead to an improvement in the physiological aspects of plants, particularly with regard to the rate of net photosynthesis. A plant that photosynthesizes more has more energy reserves available to be allocated to different metabolic functions. A decisive factor is, in particular, the purity of the mineral used. Determining the chemical-physical characteristics is in fact of particular importance in order not to run into problems during the cycle of cultivation in pots or in the open field, because a product of poor quality can cause problems of phytotoxicity on the plants in cultivation [17]. The presence of known microbial inoculations in zeolites in addition to determining an increase in the biostimulating capacity of the same, the micro-organisms in fact facilitate the passage of nutrients and water from the zeolite to the root and stimulate the plant at the hormonal level, colonizing the rhizosphere and occupying the sites of infection, can reduce the attack of telluric pathogens to the roots, ensure a greater supply of nutrients that can normally 
be removed from the indigenous micro-organisms present in the soil and anticipate and improve the functionality of zeolites $[18,12]$.

Zeolites can act as a "home" for micro-organisms as is normally the case in nature with clays. In fact, under conditions of water stress, micro-organisms take refuge inside the clay particles until the environmental conditions are suitable again to colonize the soil. The zeolites are able to interact actively with the organic components present in the soil or brought with the fertilization, and have the ability to make more available the mineral and nutritional components present within their crystal lattice, based on the needs of the plant [19]. In particular, the direct contact of zeolites with the root surface stimulates the production of mucilaginous substances (mucigel) carrying out a lubricating action that can facilitate the absorption by the root of minerals and water. The presence of certain microbial groups can also accelerate this mechanism, as they not only acidify the soil and solubilize minerals normally retained by the buffer effect, but can act as a bridge between the zeolite and the root, significantly increasing the absorption of fertilizers and water $[20,21,22]$.

\section{Conclusion}

The test showed that the presence of natural chabazite and microorganism-enriched chabazite in the growing medium can significantly improve the agronomic characteristics and germination of cabbage plants. The use of these aluminosilicates, once inserted in the soil, can also stimulate a significant increase in the chlorophyll content of the leaves and in the net photosynthesis rate of the plants, probably due to an increased supply of water and nutrients from the roots stimulated by zeolites. The presence of known microbial colonies, inside and on the surface of zeolites, can further improve the capacity of these biostimulants not only by accelerating the process of absorption of water and nutrients, but also by performing a biocontrol action towards pathogenic microorganisms.

\section{Compliance with ethical standards}

\section{Acknowledgments}

The research is part of the "chabamicro" project funded by the company Balco Greenline of Sassuolo (MO), in line with the project "Micronaturale": innovative techniques with low environmental impact for the cultivation and defense of plants.

\section{Disclosure of conflict of interest}

The author declares no conflict of interest.

\section{References}

[1] Bianco VV and Pimpini F. (1990). Orticoltura. Patron Editore, 4, 408-412.

[2] Galli E and Passaglia E. (2011). Natural Zeolites In Environmental Engineering. In: H. Holzapfel (Ed.), Zeolites In Chemical Engineering, Verlag Processeng Engineering Gmbh, Vienna, 392-416.

[3] Mumpton FA. (1978). "Natural Zeolites-A New Industrial Mineral Commodity.” In: IVaturalZeolites: Occurrence, Properties, Use, L. B, Sand and F. A. Mumpton (eds.)

[4] Gottardi GE and Galli E. (1985).Natural zeolites. sprinter-verlag, berlinheidelberg, 409.

[5] Passaglia E, Marchi E, Barbieri L, Bedogni G, Taschini G and Azzolini P. (1997). Le zeoliti nel ciclo di depurazione delle acque reflue e loro successivo impiego in agricoltura. Noi e l'Ambiente, 15, n. 52/53, 56-61.

[6] Bazzocchi R, Casalicchio G, Giorgioni ME, Loschi B, Passaglia E and Savelli C. (1996). Effetti di zeolititi Italiane sullo sviluppo del sedano. Colture Protette, 11, 91-97.

[7] Passaglia E and Poppi S. (2005). Strong reduction of irrigation water and fertilizers for vegetable and fruitgrowing on soilsamended with Italianchabaziterich rock. Epitome, 1, 2005. FIST - Federazione Italiana di Scienze della Terra. GeoItalia 2005 - Quinto Forum Italiano di Scienze della Terra, Spoleto, 21-23 Settembre 2005. Abstract volume, 96.

[8] Passaglia E and Poppi S. (2005). Risparmio idrico e di fertilizzanti nella coltivazione di ortaggi e frutta in terreni ammendati con zeolitite a chabasite. Atti $3^{\circ}$ Convegno AISSA "Il pianeta acqua nel continente agricoltura", Facoltà di Agraria dell’Università di Modena e Reggio Emilia, 6-7, 109110. 
[9] Prisa D. (2019). Germination Of Vegetable and Grassland species With Micronized chabazitic-Zeolites And Endophytic Fungi. IOSR Journal of Agriculture and Veterinary Science (IOSR-JAVS). e-ISSN: 2319-2380, p-ISSN: 2319-2372, 12(5), 32-37.

[10] Passaglia E, Marchi E and Manfredi F. (1998). Zeoliti arricchite in NH4 nella coltivazione in vaso di gerani (Pelargonium zonale). Flortecnica, novembre, 11-15.

[11] Prisa D. (2019). Effective Microorganisms and Chabazitic-Zeolites For The Improvement Quality Of Echinopsis Hybrids. Asian Academic Research Journal of Multidisciplinary, 6(2), 23-34.

[12] Prisa D. (2019). Effect of chabazitic-zeolites and effective microorganisms on growth and chemical composition of Aloe barbadensis Miller and Aloe arborescens Miller. International Journal of Agricultural Research, Sustainability, and Food Sufficiency (IJARSFS), 6(01), 315-321.

[13] Prisa D. (2019). Improvement Quality Of Impatiens And Oleander Plants With Chabazitic-Zeolites. International Journal of Recent Scientific Research, 10(04), 31727-31730.

[14] Gualtieri AF. (2000). Study of NH4+ in the zeolite phillipsite by combined synchrotron powder diffraction and IR spectroscopy. Acta Cryst., B56, 584-593.

[15] Gualtieri AF, Marchi E and Passaglia E. (1999). Zeolite content and cation exchange capacity of zeolite-rich rocks. Studies in Surface Science and Catalysis, 125, 707-713.

[16] Prisa D. (2019). Zeolites as additives for the rooting of Camellia japonica and Proteaceae Juss. The International Journal of Engineering and Science (IJES), 8(5), Series I, 10-14.

[17] Prisa D. (2019). Rhizobacteria and zeolites for overcoming saline stress in the cultivation of succulent plants. The International Journal of Engineering and Science (IJES), 8(5), Series I, 38-41.

[18] Prisa D. (2019). Cultivation and cold stress protection in Crassula with zeolitites. The International Journal of Engineering and Science (IJES), 8(6), Series I, 29-34.

[19] Mackown CT and Tucker TC. (1985). Ammonium nitrogen movement in a coarse-textured soil amended with zeolite. Soil Science Society of America Journal, 49 (2), 225-238.

[20] Prisa D. (2018).Italian chabazitic-zeolitite and Effective microorganisms for the qualitative improvement of olive trees. Atti del Convegno di Calci (PI) 2017 Atti Soc. Tosc. Sci. Nat., Mem., Supplemento, 125 (2018) pagg. 13-17.

[21] Ando $\mathrm{H}$ and Mihara C. (1996). The fate of ammonium nitrogen applied to flooded rice as affected by zeolite addition. Soil Science and Plant Nutrition, 42(3), 531-538.

[22] Ferguson GA, Pepper IL and Kneebone WR. (1987). Ammonium retention in sand amended with clinoptilolite. Soil Science Society of American Journal. 51, 231-234.

\section{How to cite this article}

Prisa D. (2019). Effect of natural zeolites and zeolites added with microorganisms for the growth of cabbage (Brassica oleracea var. capitata L.). World Journal of Advanced Research and Reviews, 4(1), 06-12. 